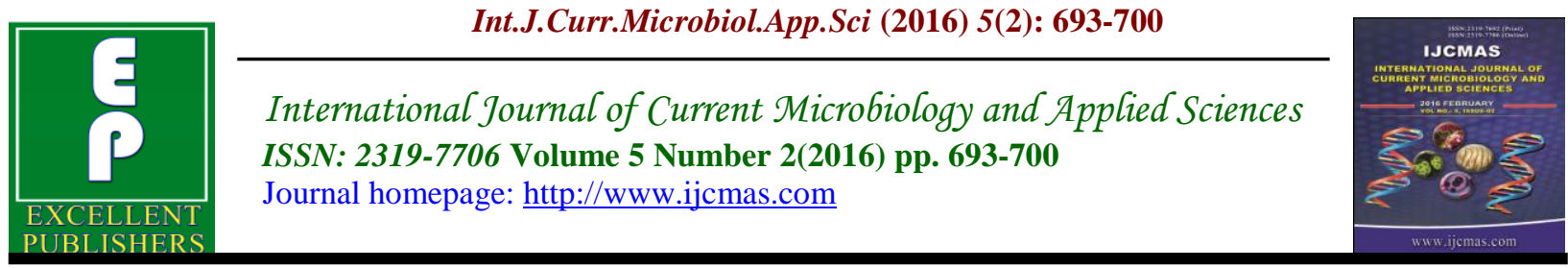

Review Article

doi: http://dx.doi.org/10.20546/ijcmas.2016.502.076

\title{
Potential of Algae in Bioremediation of Wastewater: Current Research
}

\author{
Yati Prabha*, S.K. Soni, Sharmita Gupta and Sonal
}

Spirulina Lab, Department of Botany, Faculty of Science, D.E.I., Dayalbagh University, Agra, India

*Corresponding author

\begin{tabular}{|c|c|}
\hline & B S T R A C T \\
\hline Keywords & \multirow{4}{*}{$\begin{array}{l}\text { Despite the algal diversity and relatively inexpensive algal biomass, there has been } \\
\text { little commercial exploitation of these plants for treatment of wastewater. } \\
\text { Bioremediation is a cheap and efficient method of decontamination that has } \\
\text { become increasingly popular now a days to reduce environmental pollution. In } \\
\text { urban and semi urban colonies sewage disposal has become an ecological problem. } \\
\text { The effluent discharge from residences and industries constitute a major source of } \\
\text { water pollution. A number of methods has been developed for removal of such } \\
\text { polluted substances like precipitation, evaporation, ion-exchange etc. Algae are } \\
\text { important bioremediation agents, and are already being used in wastewater } \\
\text { treatment. The potential for algae in wastewater remediation is however much } \\
\text { wider in scope than its current role. This paper identifies the area where research } \\
\text { gives to the world an "Algal Based Bioremediation" for cleaning the water bodies. } \\
\text { In this review paper we observed the effectiveness of alga for bioremediation of } \\
\text { wastewater. }\end{array}$} \\
\hline $\begin{array}{l}\mathrm{B} \\
\mathrm{B}\end{array}$ & \\
\hline ArtI & \\
\hline & \\
\hline
\end{tabular}

\section{Introduction}

As the nations growing urban major problem is the removal of wastes so humans exposed these wastes directly into rivers, these water than directly consumed by Aquatic life and so indirectly it affects the human health when human consume it with lots of disease such as Chlorella, Typhoid, Diarrhea as these disease are commonly generate through contaminated water. The availability of good quality water is necessary for preventing such disease and improving the quality of life (Oluduro and Adewoye, 2007). So some new technologies are being proposed to access the treatment of waste water.
Heavy metals such as Lead, cadmium, mercury, nickel, zinc, aluminum, arsenic, copper and iron are mentioned as environmental pollutants which cause severe poisoning conditions (Derek, 1999; Dias et al, 2002; Ballantyne et al, 1999). Bioremediation is a pollution control technology that uses biological system to catalyze the degradation or transformation of various chemicals to less harmful forms. Developing of biological based treatment system considered as economically cheaper and more environment friendly (Valderrama, 2002). Algal bioremediation 
are being used in waste water treatment as its potential in waste water remediation is much wider in scope then its current role (Volesky, 1990; Wase and Foster, 1997) so this review paper gives overall picture to use by microalgae for bioremediation of water bodies.

\section{Reports of Some Algae in Heavy Metal Uptake}

Bioaccumulation process is known as an active mode of metal accumulation by living cells which depend on the metabolic activity of the cells (Volesky 1990; Wase and Foster, 1997). The idea that microalgae help in bioaccumulation of heavy metals was firstly proposed by Oswald and Gootas in 1957 but this topic gained attention recently by
Oswald 1988 and Doshi et al, 2007. It has been observed that microalgae are so efficient in uptake of heavy metals from effluent water (Kajan et al, 1992). Heavy metal contamination of agricultural soils has become a serious issue in crop production and human health in many developed countries of the world. Techniques presently in existence for removal of heavy metals from contaminated water include reverse osmosis, electro dialysis, ultra filtration, ionexchange, chemical precipitation, phytoremediation etc. Table 1 indicates the ability of algae to absorb different organic and inorganic pollutants from water (Industrial effluents, sewage water, pond water, oil effluents, heavy metals etc) which has been recognized from many years.

Table.1 Algae Involve in the Bioremediation of Different Pollutants Present in Wastewater

\begin{tabular}{|c|c|c|c|}
\hline Pollutant & $\begin{array}{l}\text { Algal genera used to } \\
\text { bioremediate it }\end{array}$ & Summary of Result & References \\
\hline $\begin{array}{l}\text { Copper }(\mathrm{Cu}) \quad \text { and } \\
\text { Iron }(\mathrm{Fe})\end{array}$ & Anabena doliolum & $\begin{array}{l}\text { Immobilized cyanobacteria is very potential in } \\
\text { metal removal than free living cell as } \\
\text { immobilized algae show increase in uptake of } \\
\text { Copper and Iron upto } 45 \% \text { and } 23 \% \text { higher } \\
\text { than free living cells }\end{array}$ & $\begin{array}{l}\text { Rai and Mallic, } \\
1992\end{array}$ \\
\hline $\begin{array}{l}\operatorname{Lead}(\mathrm{Pb}), \\
\text { Cadmium }(\mathrm{Cd}), \\
\text { Copper }(\mathrm{Cu}), \\
\operatorname{Nickel}(\mathrm{Ni}) \quad \text { and } \\
\text { Zinc(Zn) }\end{array}$ & Sargassum fluitans & $\begin{array}{l}\text { Studies of S.fluitans regarding adsorption of } \\
\text { heavy metals uptake was depend upon the size } \\
\text { of particle. Lead is found to be the best sorbed } \\
\text { metal followed by others in decreasing order. } \\
\text { Adsorption capacity of glutaraldehde cross } \\
\text { linked } S \text {. fluitans is } \mathrm{Pd}>\mathrm{Cd}>\mathrm{Cu}>\mathrm{Ni}>\mathrm{Zn}\end{array}$ & Leusch et al, 1995 \\
\hline $\begin{array}{l}\text { Ammonia }\left(\mathrm{NH}_{3}\right) \\
\text { and Phosphorous }\end{array}$ & $\begin{array}{l}\text { Chlorella vulgaris } \\
\text { and Scenedesmus } \\
\text { dimorphus }\end{array}$ & $\begin{array}{l}\text { C. vulgaris and } S \text {. dimorphus is also an } \\
\text { efficient microalgae in the removal of } \mathrm{NH}_{3} \\
\text { and phosphorous during biotreatment of } \\
\text { agroindustrial waste water of dairy industry. } \\
\text { Both theses algae remove phosphorous from } \\
\text { wastewater in cylindrical bioreactor. C. } \\
\text { vulgaris is superior for removal of ammonia } \\
\text { in triangular bioreactor while the cylindrical } \\
\text { bioreactor was superior in removal of } \\
\text { phosphorous. }\end{array}$ & $\begin{array}{l}\text { Gonzalez et al, } \\
1997\end{array}$ \\
\hline Copper(II) & Padina sps. & $\begin{array}{l}\text { Pre treatment biomass of Padina sps. could be } \\
\text { used as an efficient biosorbent for the } \\
\text { treatment of Copper (II) containing } \\
\text { wastewater stream. biosorption capacities }\end{array}$ & Kaewsarn, 2002 \\
\hline
\end{tabular}




\begin{tabular}{|c|c|c|c|}
\hline & & $\begin{array}{l}\text { were solution dependent and the maximum } \\
\text { capacity obtained was } 0.08 \mathrm{~m} \text { mol/g at a } \\
\text { solution } \mathrm{pH} \text { of about } 5 \text {. Biosorption kinetics } \\
\text { was found to be fast with } 90 \% \text { adsorption in } \\
15 \mathrm{~min} \text {. }\end{array}$ & \\
\hline $\operatorname{Lead}(\mathrm{Pb})$ & Spirulina & $\begin{array}{l}\text { In the initial stage }(0-12 \mathrm{~min}) \text { the adsorption } \\
\text { rate of Spirulina is so high that it adsorbs } 74 \% \\
\text { metal biologically and its biosorption capacity } \\
\text { was estimated to be } 0.62 \mathrm{mg} \text { Lead per } 10^{5} \text { alga } \\
\text { cells. }\end{array}$ & $\begin{array}{l}\text { Hong and Shan- } \\
\text { Shan, } 2005\end{array}$ \\
\hline Copper(II) & $\begin{array}{l}\text { Cladophora } \\
\text { fascicularis }\end{array}$ & $\begin{array}{l}\text { Biosorption is an effective means of removal } \\
\text { of heavy metals from waste water. In this the } \\
\text { biosorption behavior of } C \text {.fascularis has been } \\
\text { investigated as a function of pH, amount of } \\
\text { biosorbent, initial copper ions concentration, } \\
\text { temperature and co-existing. }\end{array}$ & Deng et al,2007 \\
\hline Lead(II) & Spirogyra & $\begin{array}{l}\text { Spirogyra found to be an effective alga in } \\
\text { Lead removal. It was observed that maximum } \\
\text { adsorption capacity of } \mathrm{Pb}(\mathrm{II}) \text { ion was around } \\
140 \mathrm{mg} \text { metal/g of biomass at } \mathrm{pH} 5.0 \text { in } \\
100 \mathrm{~min} \text { with } 200 \mathrm{mg} / \mathrm{L} \text { of initial } \\
\text { concentration }\end{array}$ & $\begin{array}{l}\text { Gupta and Rastogi, } \\
2008\end{array}$ \\
\hline $\begin{array}{l}\text { Copper }(\mathrm{Cu}), \\
\text { Cadmium }(\mathrm{Cd}) \text { and } \\
\operatorname{Lead}(\mathrm{Pb})\end{array}$ & Chlorella vulgaris & $\begin{array}{l}\text { Dried dead C.vulgaris was studied in terms of } \\
\text { its performance in binding divalent } \mathrm{Cu}, \mathrm{Cd} \\
\text { and } \mathrm{Pb} \text { ions from their aqueous solutions. } \\
\text { Percentage uptake of cadmium ions exhibited } \\
\text { general decrease with decrease in dielectric } \\
\text { constant values while that of copper, Lead } \\
\text { ions shows decrease with increase in donor } \\
\text { numbers }\end{array}$ & Al- Qunaibit, 2009 \\
\hline Oil effluents & $\begin{array}{l}\text { Scenedesmus } \\
\text { obliques }\end{array}$ & $\begin{array}{l}\text { Biological oxygen demand (BOD) and } \\
\text { Chemical Oxygen Demand (COD) level was } \\
\text { reduced up to } 16.66 \% \text { and } 82.80 \% \text { by } \\
\text { S.obliques. Reduction of BOD and COD } \\
\text { levels might occur due to the removal of the } \\
\text { Dissolved Organic compounds and derivatives } \\
\text { by some extent from the effluents during } \\
\text { treatment process. Treatment of refinery } \\
\text { effluents with S.obliques is an effective } \\
\text { technology in the reduction of pollutants. }\end{array}$ & $\begin{array}{l}\text { Rajasulochana et } \\
a l, 2009\end{array}$ \\
\hline $\begin{array}{l}\text { Cadmium }(\mathrm{Cd}) \\
\text { cations }\end{array}$ & $\begin{array}{l}\text { Scenedesmus } \\
\text { obliquus }\end{array}$ & $\begin{array}{l}\text { Viable biomass removed metal to a maximum } \\
\text { extent of } 11.4 \mathrm{mg}_{\mathrm{Cd}} / \mathrm{g} \text { at } 1 \mathrm{mg}_{\mathrm{Cd}} / 1 \text {, with most } \\
\mathrm{Cd}^{2+} \text { being adsorbed onto the cell surface. A } \\
\text { commercially available strain (ACOI 598) of } \\
\text { the same microalga species was also exposed } \\
\text { to the same Cd concentrations, and similar } \\
\text { results were obtained for the maximum extent } \\
\text { of metal removal. Heat-inactivated cells } \\
\text { removed a maximum of } 6.04 \mathrm{mg}_{\mathrm{Cd}} / \mathrm{g} \text { at } \\
0.5 \mathrm{mg}_{\mathrm{Cd}} / \mathrm{l} \text {. The highest extent of metal }\end{array}$ & $\begin{array}{l}\text { Monteiro et al, } \\
2009\end{array}$ \\
\hline
\end{tabular}




\begin{tabular}{|c|c|c|c|}
\hline & & $\begin{array}{l}\text { removal, analyzed at various } \mathrm{pH} \text { values, was } \\
0.09 \mathrm{mg}_{\mathrm{Cd}} / \mathrm{g} \text { at } \mathrm{pH} 7.0 \text {. }\end{array}$ & \\
\hline $\begin{array}{lr}\text { Biological } & \text { Oxygen } \\
\text { Demand } & \text { (BOD) } \\
\text { and } & \text { Chemical } \\
\text { Oxygen } & \text { Demand } \\
\text { (COD) } & \end{array}$ & Oscillatoria & $\begin{array}{l}\text { The effectiveness of Cyanobacteria treatment } \\
\text { system for bioremediation of textile effluents } \\
\text { has been investigated by the use of } \\
\text { Oscillatoria. Results revealed that there was } \\
\text { the } 57.6 \% \text { and } 39.82 \% \text { decrease in COD and } \\
\text { BOD }\end{array}$ & $\begin{array}{l}\text { Abraham } \\
\text { Nanda, } 2010\end{array}$ \\
\hline $\begin{array}{l}\operatorname{Cadmium}(\mathrm{Cd}) \text { and } \\
\operatorname{Copper}(\mathrm{Cu})\end{array}$ & Sargassum sinicola & $\begin{array}{l}\text { Non-living biomass of S. sinicola showed a } \\
\text { significant result on the biosorption of Cd and } \\
\mathrm{Cu} \text { ions. By batch experiments ability to } \\
\text { remove } \mathrm{Cd} \text { is significantly slows down from } \\
81.8 \% \text { to } 5.8 \% \text { while of } \mathrm{Cu} \text { remains high from } \\
89 \text { to } 80 \% \text { at a range of salinity from } 0-40 \mathrm{psu} \text {. } \\
\text { Maximum capacity of biosorption was } \\
3.44 \mathrm{mg} / \mathrm{g} \text { for } \mathrm{Cd} \text { and } 116 \mathrm{mg} / \mathrm{g} \text { for } \mathrm{Cu} \text { at } \\
35 \mathrm{psu} \text {. }\end{array}$ & Prado et al, 2010 \\
\hline $\begin{array}{l}\operatorname{Mercury}(\mathrm{Hg}), \\
\operatorname{Cadmium}(\mathrm{Cd}) \text { and } \\
\operatorname{Lead}(\mathrm{Pb})\end{array}$ & Dunaliella & $\begin{array}{l}\text { Dunaliella alga tolerates high concentration of } \\
\text { heavy metals and it has a great ability to } \\
\text { absorb metals from aquatic environments. It is } \\
\text { concluded that the amount of } \mathrm{Cd}, \mathrm{Pb} \text { and } \mathrm{Hg} \\
\text { ions adsorption was not increase in aqueous } \\
\text { solution with increase in time. Amount } \\
\text { adsorbed remained fairly constant with time } \\
\text { during competitive sorption }\end{array}$ & Imani et al, 2011 \\
\hline $\begin{array}{l}\text { Biological Oxygen } \\
\text { Demand (BOD), } \\
\text { Chemical Oxygen } \\
\text { Demand (COD), } \\
\text { Dissolved Oxygen } \\
\text { (DO), } \mathrm{NH}_{3}, \text { Nitrate, } \\
\text { Magnesium, } \\
\text { Organic } \\
\text { Inorganic } \\
\text { Phosphates }\end{array}$ & $\begin{array}{l}\text { Oscillatoria, } \\
\text { Synechococcus, } \\
\text { Nodularia, Nostoc } \\
\text { and Cyanothece }\end{array}$ & $\begin{array}{l}\text { Contaminants Removal Efficiency(RE) } \\
\text { percentage of cyanobacterial species } \\
\text { (Oscillatoria, Synechococcus, Nodularia, } \\
\text { Nostoc and Cyanothece) ranged between } \\
69.5 \% \text { and } 99.6 \% \text { at } 5 \mathrm{ppm}, 83.9 \% \text { and } 99.7 \% \\
\text { at } 10 \mathrm{ppm} \text { and maximum between } 95.5 \% \text { and } \\
99.7 \% \text { mixed culture removal efficiency } \\
\text { percentage range is between } 91.6 \text { and } 100 \% \\
\text { while at 10ppm. Result indicates the potential } \\
\text { of natural resources as efficient agents for } \\
\text { pollution control }\end{array}$ & Dubey et al, 2011 \\
\hline $\begin{array}{l}\text { Phosphorous, } \\
\text { Ammonia nitrogen, } \\
\text { Nitrite } \quad \text { Nitrogen } \\
\text { and } \\
\text { Nitrogen }\end{array}$ & $\begin{array}{l}\text { Isochrysis } \\
\text { zhanjiangenesis }\end{array}$ & $\begin{array}{l}\text { Isochrysis zhanjiangenesis from the culture of } \\
\text { Cyanoglossus semilaevis in } \mathrm{pH} 7,5000 \mathrm{Lux} \\
\text { illumination and original inoculation density } \\
0.01 \mathrm{mg} / \mathrm{l} \text { microalgae could eliminate } \\
78 \% \text { active phosphorous, } 100 \% \text { ammonia } \\
\text { nitrogen, } 62.3 \% \text { nitrite nitrogen and } 84.7 \% \\
\text { nitrate nitrogen in waste water within } 11 \text { days. }\end{array}$ & Zheng et al, 2011 \\
\hline $\operatorname{Cadmium}(\mathrm{Cd})$ & $\begin{array}{l}\text { Spirogyra sps. and } \\
\text { Oscillatoria sps. }\end{array}$ & $\begin{array}{l}\text { Different concentration of } \mathrm{Cd} \text { has been } \\
\text { examined in cultures of Spirogyra sps. and } \\
\text { Oscillatoria sps. Photosynthetic pigments of } \\
\text { chlorophyll, sugar, protein and proline } \\
\text { contents shows decreasing trends with } \\
\text { increase of Cd ions from waste water }\end{array}$ & $\begin{array}{l}\text { Brahmbhatt et al, } \\
2012\end{array}$ \\
\hline
\end{tabular}




\begin{tabular}{|c|c|c|c|}
\hline $\begin{array}{l}\text { Chemical Oxygen } \\
\text { Demand(COD) and } \\
\text { Phenolic } \\
\text { Compounds }\end{array}$ & $\begin{array}{l}\text { Chlorella vulgaris, } \\
\text { Spirulina platensis } \\
\text { and Dunaliella saline }\end{array}$ & $\begin{array}{l}\text { C. vulgaris, S.platensis and D.saline were } \\
\text { found to be an efficient algae in decreasing the } \\
\text { amount of COD and phenolic compounds } \\
\text { from olive mill waste water }\end{array}$ & Ismael et al, 2012 \\
\hline $\begin{array}{l}\text { Cadmium }(\mathrm{Cd}), \\
\operatorname{Mercury}(\mathrm{Hg}), \\
\text { Lead(Pb), } \\
\text { Arsenic(Ar) and } \\
\text { Cobalt(Co) }\end{array}$ & Spirogyra hyaline & $\begin{array}{l}\text { Dried biomass of } S \text {. hyaline used for removal } \\
\text { of these heavy metals. Highest amount of } \mathrm{Cd} \text {, } \\
\mathrm{Hg} \text { and } \mathrm{Ar} \text { was absorbed when initial heavy } \\
\text { metal concentration was } 40 \mathrm{mg} / \mathrm{l} \text { whereas Lead } \\
\text { and Cobalt exhibited greatest removal at } \\
80 \mathrm{mg} / \mathrm{l} \text {. metal uptake for dried biomass was } \\
\text { found in the ordered } \mathrm{Hg}>\mathrm{Pb}>\mathrm{Cd}>\mathrm{Ar}>\mathrm{Co}\end{array}$ & $\begin{array}{l}\text { Kumar and } \\
\text { Oommen, } 2012\end{array}$ \\
\hline Crude Oil & $\begin{array}{l}\text { Aphanocapsa sps., } \\
\text { Chlorella } \\
\text { autotrophica, } \\
\text { Coccochloris } \\
\text { elabens, Dunaliella } \\
\text { tertiolecta, } \\
\text { Oscillatoria sps., } \\
\text { Scenedesmus } \\
\text { obliques, } \\
\text { Synechococcus } \\
\text { elongates and Volvox }\end{array}$ & $\begin{array}{l}\text { These algae were helpful in the degradation of } \\
35 \% \text { of the crude and they remain alive also in } \\
\text { high crude condition abilities that are } \\
\text { necessary for bioremediation. Results } \\
\text { demonstrate that properly controlled algae are } \\
\text { feasible agents for crude oil bioremediation. }\end{array}$ & Cao et al, 2013 \\
\hline $\begin{array}{l}\text { Phosphate, Nitrate, } \\
\text { COD and BOD }\end{array}$ & $\begin{array}{l}\text { Chlorella vulgaris } \\
\text { and Scenedesmus } \\
\text { quadricauda }\end{array}$ & $\begin{array}{l}\text { Removal efficiencies of COD, BOD, Nitrate } \\
\text { and Phosphate of waste water were } 80.64 \% \text {, } \\
70.91 \%, 78.08 \% \text { and } 62.73 \% \text { respectively } \\
\text { using C. vulgaris up to } 15 \text { days while using } S \text {. } \\
\text { quadricauda the removal efficiencies of COD, } \\
\text { BOD, Nitrate and Phosphate of waste water } \\
\text { were } 70.96 \%, 89.21 \%, 70.32 \% \text { and } 81.34 \% \\
\text { respectively up to } 15^{\text {th }} \text { days }\end{array}$ & Kshirsagar, 2013 \\
\hline $\begin{array}{l}\text { Phosphorous and } \\
\text { Nitrate }\end{array}$ & $\begin{array}{l}\text { Chlorella } \\
\text { minutissima }\end{array}$ & $\begin{array}{l}\text { The amount of Phosphorous in water sample } \\
\text { treated with } C \text {. minutissima reduced from } \\
4.47 \mathrm{ppm} \text { to } 1.15 \mathrm{ppm} \text { while reduction of } \\
\text { Nitrate is from } 3.6 \mathrm{ppm} \text { to } 0.3 \mathrm{ppm} \text {. removal } \\
\text { effeciencies of } C \text {. minutissima was very high. }\end{array}$ & $\begin{array}{l}\text { Sharma and Khan, } \\
2013\end{array}$ \\
\hline Lead & $\begin{array}{l}\text { Enteromorpha algae } \\
\text { and its silicates } \\
\text { bonded material }\end{array}$ & $\begin{array}{l}\text { Lead adsorption capacity was } 83.8 \mathrm{mg} / \mathrm{g} \text { at } \mathrm{pH} \\
3 \text { with algae and } 1433.5 \mathrm{mg} / \mathrm{g} \text { for silicates } \\
\text { modified algae. Thomas and Yoon Nelson } \\
\text { Column Model were best for adsorbent (E) } \\
\text { and Algae after reflux (ER) and Yan model } \\
\text { for (EM) with capacity } 76.2,71.1 \text { and } \\
982.5 \mathrm{mg} / \mathrm{g} \text { respectively. EM and ER show less } \\
\text { swelling and better flow rate control than E }\end{array}$ & $\begin{array}{l}\text { Hammud et al, } \\
2014\end{array}$ \\
\hline Copper $(\mathrm{Cu})$ ions & Spirulina platensis & $\begin{array}{l}\text { Adsorption of } \mathrm{Cu} \text { ions was found to increase } \\
\text { gradually along with decrease in biomass } \\
\text { concentration. Biosorption was found to be } \\
\text { maximum }(90.6 \%) \text { in a solution containing } \\
100 \mathrm{mg} \mathrm{Cu} / 1 \text { at ph } 7 \text { with } 0.050 \text { dried biomass } \\
\text { of algae at } 37^{\circ} \mathrm{C} \text { with } 90 \text { min contact time. }\end{array}$ & Homaidan, 2014 \\
\hline
\end{tabular}




\begin{tabular}{|c|c|c|c|}
\hline $\begin{array}{l}\text { Copper(Cu) and } \\
\text { Zinc(Zn) }\end{array}$ & $\begin{array}{l}\text { Chlorella vulgaris, } \\
\text { Spirulina maxima } \\
\text { and Synechocystis } \\
\text { sps. }\end{array}$ & $\begin{array}{l}\text { Microalgae removed up to } 81.7 \% \mathrm{Cu} \text { reaching } \\
\text { lowest final concentration of } 7.8 \mathrm{ppb} \text { after } 10 \\
\text { days. } \mathrm{Zn} \text { reduced up to } 94.1 \% \text { reaching } 0.6 \mathrm{ppb} \\
\text { after } 10 \text { days. Inoculated samples show } \\
\text { decreased heavy metal concentration within } 6 \\
\text { hrs of initial inoculation as microalgae don't } \\
\text { require long period }\end{array}$ & Chan et al, 2014 \\
\hline $\begin{array}{l}\text { Textile waste } \\
\text { effluents(Color and } \\
\text { COD) }\end{array}$ & Chlorella vulgaris & $\begin{array}{l}\text { Cultivation of } C \text {. vulgaris present maximum } \\
\text { cellular concentration } \mathrm{C}_{\max } \text { and maximum in } \\
\text { specific growth rates } \mu_{\max } \text { in waste water } \\
\text { concentration of } 5 \% \text { and } 17.5 \% \text {. Highest COD } \\
\text { and color removal occurred with } 17.5 \% \text { of } \\
\text { textile water effluents. C.vulgaris culture in } \\
\text { textile waste effluent demonstrated the } \\
\text { possibility of using this microalga for COD } \\
\text { and Color removal. }\end{array}$ & $\begin{array}{l}\text { Kassas and } \\
\text { Mohamed, } 2014\end{array}$ \\
\hline $\begin{array}{l}\text { Chromium }(\mathrm{Cr}) \text { and } \\
\operatorname{Lead}(\mathrm{Pb})\end{array}$ & $\begin{array}{l}\text { Chlorella } \\
\text { (Butcher) }\end{array}$ & $\begin{array}{l}\text { Seven days incubation of C.marina in waste } \\
\text { water increased from } 3 \times 10^{6} \text { to } 1.5 \times 10^{7} \text { cell } / \mathrm{ml} \\
\text { and it reduced } 88 \% \text { Nitrate, } 64 \% \text { Ammonia, } \\
75 \% \text { Nitrate and } 51 \% \text { Phosphorous overall. } \\
\text { Heavy metals such as Chromium and Lead } \\
\text { largely remove the } \% \text { of these metals upto } \\
89 \% \text { and } 87 \% \text { respectively }\end{array}$ & Kumar et al, 2015 \\
\hline
\end{tabular}

In conclusion, these reviews indicate the potential of Algae for the removal of different pollutants such as industrial waste, oil effluents, organic and inorganic pollutants etc from wastewater. With the advantages of low cost raw material and no secondary pollution, algae is promising for purification of waste water containing heavy metals.

\section{Acknowledgement}

Express my gratitude to Botany Department, Dayalbagh Educational Institute, Agra for their guidance and to carry out this valuable research paper.

\section{References}

Abraham Jayathi and Sonil Nanda.2010. Evaluation of Textile Effluents before and After Treatment with Cyanobacteria. $J$ of Industrial Pollution Control 26(2) pp 149-152.

Al-Homaidan A. Ali, Hadel J. Al-Houri, Amal
A. Al-Hazzani, Gehan Elgaaly, Nadine M.S.Moubayed. 2014.Arabian Journal of Chemistry. Vol 7(1):57-62.

Al-Qunaibit M. H.2009. Divalent $\mathrm{Cu}, \mathrm{Cd}$, and $\mathrm{Pb}$ Biosorption in Mixed Solvents. Bioinorganic Chemistry and Applications.

Ayodhya D Kshirsagar. 2013.Bioremediation of waste water by using microalgae: An experimental Study. Int. J. LifeSci. Bt. \& Pharma Res. Vol. 2, No. 3.

Ballantyne B, Timothy CM, Tore S. 1999.General and Applied Toxicology, Second Edition. Vol. 3, Macmillan Publishers. pp. 2052-2062, 2145-2155.

Brahmbhatt N.H., Patel V. Rinku and Jasrai R.T.2012. Bioremediation Potential of Spirogyra sps. and Oscillatoria sps. for Cadmium. Asian Journal of Biochemical and Pharmaceutical Research.Vol 2. Issue 2.

Cao Xiuqi, Ying Xiong and Janelle Lund.2013. The effects of micro-algae characteristics on the bioremediation rate of Deepwater Horizon Crude Oil. Journal of Emerging Investigators. 
Chan Alison, Hamidreza Salsali and Ed McBean.2014. Heavy Metal Removal (Copper and Zinc) in secondary effluents from waste water treatment plants by Microalgae.ACS Sustainable Chemistry and Engineering, Vol. 2: issue 2 pp 130137.

Chen H. and Pan Shan Shan.2005. Bioremediation potential of Spirulina Toxicity and Biosorption Studies of Lead. J. Zhejiang Univ. Sci. 6B (3):171-174.

Deng Liping, Xiaobin Zhu, Xinting Wang, Yingying $\mathrm{Su}$ and Hua su.2007. Biosorption of copper (II) from aqueous solutions by green alga Cladophora fascicularis. Biodegradation 18:393-402.

Derek WJ.1999. Exposure or Absorption and the Crucial Question of Limit for Mercury, J. Can. Dent. Assoc., 65: 42-46.

Dias MA.2002. Removal of heavy metals by an Aspergillus terreus strain immobilized in polyurethane matrix. Lett. Appl.Microbiol.34 (1): 46-50.

Doshi H., Ray A., Kothari IL. 2007.Bioremediation potential of dead and live Spirulina: Spectroscopic, Kinetics and SEM studies. Biotechnol Bioeng 96(6):1051-1063.

Dubey Sanjay Kumar, Jaishree Dubey, Sandeep Mehra, Pradeep Tiwari and A.J. Bishwas.2011.Potential Use Of Cyanobacterial Species in Bioremediation Of industrial Effluents. American Journal of Biotechnology. Vol10 (7). Pp.11251132.

Gonzalez Luz Estela, Rosa Olivia Canizares and Sandra Baena, 1997. Efficiency of ammonia and phosphorous removal from a Colombian agro industrial wastewater by the microalgae Chlorella vulgaris and Scenedesmus dimorphus. Bioresource Technology Vol. 60: 259-262.

Gulshan Kumar Sharma and Shakeel Ahmad Khan.. Bioremediation of Sewage Wastewater using Selective Algae for Manure Production. 2013. International Journal of Environmental Engineering and Management. ISSN 2231-1319, Vol. 4, No. 6, pp 573-580
Hala Yassin El- Kassas and Laila Abdelfattah Mohamed .2014.The Egyptian Journal of Aquatic Research.Vol. 40(3):301-308.

Hammud H. Hasan, Ali El-Shaar, Essam Khamis and El- Sayed Mansour. 2014. Adsorption Studies of Lead by Enteromorpha Algae and its silicates Bonded Material. Advances in Chemistry. Vol. Article ID 205459, 11 pages.

Imani Saber, Rezaei-Zarchi Saeed, Hashemi Mehrdad, Borna Hojjat, Javid Amaneh, Ali mohamad $\mathrm{Z}$ and Hossein Bari Abarghouei. 2011. Hg, Cd and Pb heavy metal bioremediation by Dunaliella alga. Journal of Medicinal Plants Research Vol. 5(13), pp. 2775-2780, 4 July.

Ismail., Azza A.M. Abd EL-All and Hanan A.M. 2013. Hassanein. Biological influence of some microorganisms on Olive Mill Waste Water. Egypt J. Agric. Res., 91(1) .

J. Zheng, J.M. Hao, B. Wang and C. Shui. 2011. Bioremediation of Agriculture Wastewater by Microalgae Isochrysis zhanjiangensis and production of the Biomass Material. Key Engineering Material, Vols 460-461, pp. 491-495.

Kaewsarn Pairat. 2002. Biosorption of Copper (II) from aqueous solutions by pre-treated biomass of marine algae Padina sp. Chemosphere 47:1081-1085.

Kajan M., Livansky K. and Binova J. 1992. Archiv fur Hydrobiologie. Supplement 93:93.

Kumar Dinesh, S.P. Santhanam, T. Jayalakshmi, R. Nandakumar, S. Ananth, A. Shenbaga Devi and B. Balaji Prasath. 2015. Excessive nutrients and heavy metals removal from diverse waste waters using marine microalga Chlorella marina (Butcher).Indian Journal of Geo-Marine Sciences. Vol.44 (1) .

Kumar JI and Oammen C. 2012. Removal of Heavy Metals by Biosorption using freshwater alga Spirogyra hyaline. $J$. Environ Biol. Vol. 33(1):27-31.

Leush A., Holan ZR, Volesky B. 1995. Biosorption of Heavy Metals $(\mathrm{Cd}, \mathrm{Cu}, \mathrm{Ni}$, $\mathrm{Pb}, \mathrm{Zn}$ ) by chemically reinforced biomass 
of marine algae. J. Chem Technol. Biotechnol 62:279-28.

Monteiro Cristina M., Paula M. L. Castro and F. Xavier Malcata (2009). Solutions. WORLD. Volume 1573-1578

Oluduro AO and Adewoye BI. 2007.Efficiency of moringa Oleifera Sead extract on the microflora of surface and ground water J. plant Sci. 6:453-438.

Oswald W and Gootas HB.1957. Photosynthesis in sewage treatment. Trans Am Soc Civ Eng 122:73-105.

Oswald WJ. 1988. Microalgae and Waste water treatment. In: Borowizka, MA and L.J. Borowitzka. Editors. Microalgal Biotechnology. Cambridge University Press. P. 305-328.

Prado Monica Patron-, Baudilio AcostaVargas, Elisa Serviere- Zaragoza and Lia C. Mendez- Rudriguez. 2010. Copper and Cadmium Biosorption By dried Seaweed Sargassum sinicola in saline wastewater. Water Air Soil Pollut 210: 197-202.

Prado Monica Patron-, Margarita CasaValdez, Tania Zenteno- Savin, Daniel B.Lluch-Cota, Elisa Serviere- Zaragoza and Lia C. Mendez- Rudriguez. 2011. Biosorption Capacity for Cadmium Of Brown Seaweed Sargassum sinicola and Sargassum lapazeanum in the Gulf of California. Water, Air and Pollution. Vol
221, No.1-4, pp 137-144.

Rai LC and Mallich N 1992. Removal and assessment of toxicity of $\mathrm{Cu}$ and $\mathrm{Fe}$ to Anabena doliolum and Chlorella vulgaris using free and immobilized cells. World J. Microbiol. Technol 8:110-114.

Rajasulochana, P., Dhamotharan, R., Murgesan, S. and Rama Chandra Murthy A. 2009. Journal of American Science; 5(4): 17-22.

V.K. Gupta, A. Rastogi .2008.Biosorption of Lead from aqueous solutions by green algae Spirogyra species: Kinetics and equilibrium studies. Journal of Hazardous Materials. Volume 152, Issue 1, Pages 407-414

Valderrama, L. T., C. M. Del Campo, C. M. Rodriguez, L. E. De Bashan and Y. Bashan. 2002. Treatment of recalcitrant wastewater from ethanol and citric acid production using the microalga Chlorella vulgaris and the macrophyte Lemna minuscula. Water Research, 36 (17): 4185-4192.

Volesky B.1990. Biosorption of heavy metals, Boca Raton, Flo.: Press CRC, Florida. pp 3-6().

Wase J. and Forster C.F.1997., Biosorbents for metals ions: Taylor\& Francis. Lo.

\section{How to cite this article:}

Yati Prabha, S.K. Soni, Sharmita Gupta and Sonal. 2016. Potential of Algae in Bioremediation of Wastewater: Current Research. Int.J.Curr.Microbiol.App.Sci.2016.5(2): 693-700. doi: http://dx.doi.org/10.20546/ijcmas.2016.502.076 